\title{
The Haunting Affect of Place in the Discourse of the Virtual
}

\section{Introduction}

The Dutch architect Rem Koolhaas once said that, 'the only space that matters in our time is the one we connect to on the computer' (quoted in Knack, 2000). While partly tongue-in-cheek, Koolhaas's remark nevertheless conveys a sentiment that historically is not uncommon in writing on new media.

His remark also connects with established arguments that electronic media impact dramatically on our experience and understanding of place. For example, in his influential (1985) book, No Sense of Place, Joshua Meyrowitz writes:

Changes in media in the past have always affected the relationship among places. They have affected the information that people bring to places and the information that people have in given places. But the relationship between place and social situation was still quite strong. Electronic media go one step further: They lead to a nearly total dissociation of physical place and social "place". When we communicate through telephone, radio, television, or computer, where we are physically no longer determines where and who we are socially (Meyrowitz, 1985, p. 115).

The focus of this paper is on the last of these media: the computer. More precisely, it is concerned with tracing how the notion of place circulates and is understood in the literature from the 1980s and 1990s on computer-mediated information and communications technologies - which for the sake of brevity will be referred to hereafter as the discourse of the virtual. 
The paper is divided into three parts. The first provides a brief account of at least two ways that the notion of place circulates in the discourse of the virtual (especially CMC). The second outlines Jacques Derrida's critique of spatial metaphor in the text of philosophy. The third and final part of the paper uses Derrida's critique to explore how we might understand the 'place' of place in the discourse of the virtual. The argument that is developed here is that Derrida's reading of spatial (especially architectural) metaphor in the text of philosophy parallels the use of spatial metaphor in the discourse of the virtual. These parallels hold important implications for thinking about place and the virtual. Three further observations will be developed in light of this in conclusion.

\section{Place in the Discourse of the Virtual: An Ambiguous Presence}

The 1980s and 1990s witnessed a prodigious output of populist and academic literature that sought to make sense of virtual technologies. In these texts (especially the former variety), the notion of place holds an ambiguous, almost double, presence.

On the one hand, it is argued that networked computing technologies facilitate a form of space which Lev Manovich (n.d.) suggests 'may be unique to new media'. William Gibson (1993) famously called this 'cyberspace'. Manovich calls it 'computer space’ or 'navigable space'. He writes:

For the first time, space becomes a media type. Just as other media types audio, video, stills, and text - it can be now instantly transmitted, stored and retrieved, compressed, reformatted, streamed, filtered, computed, programmed and interacted with (Manovich, n.d.). 
Characterising many accounts from the period of the late-1980s and 1990s was a strong techno-boosterist rhetoric that conceived of this 'new' media space as a dematerialised space (Benedikt, 1992, p. 14), and a disembodied space free from the constraints of geography and physics and, in more extreme cases, the messy contingencies of the flesh. For example, architectural theorist Neil Spiller (1998, p. 34) writes:

It might now be possible for the self to discard the oldest prosthetic of all, the body. With the cyberspace prosthetic it may be possible to escape the 'meat' for good, with no harm caused.

Spiller refers to this 'post-human' retreat into the abstract realm of cyberspace as 'visceral escapology'; those who quibble about the abandonment of the body he derisively labels 'flesh chauvinists' and 'flesh Luddites' (Spiller, 1998, pp. 137 \& 139).

On the other hand, and at the same time that cyberspace is cast as a dematerialised space free from geographical constraint, place-based metaphors emerged as critical to the conceptualisation of these spaces, especially in the interface design of sites for 'virtual community' and the exchange of computer-mediated communication (hereafter shortened to $\mathrm{CMC}$ ). This is not surprising. The obvious appeal of placebased architectural and urban metaphors in interface design is that they add stability and spatial form to abstract data flows and CMC exchange. They foster a sense of togetherness by recreating in symbolic form familiar everyday social settings, such as 
cafés, bars and other meeting places. In other words, these metaphors and associated iconography invoke a 'sense of place'.

Before exploring these ideas further, it is necessary to give some consideration to the concept of place in its own right. Part of the difficulty in dealing with the notion of place has and continues to be its perceived lack of definitional clarity and precision. There are many different definitions and approaches to conceiving of place, all of which highlight its complexity. Basic dictionary definitions do little to resolve general understanding of the term. ${ }^{2}$ This is because, "place is not just the "where" of something; it is the location plus everything that occupies that location seen as an integrated and meaningful phenomenon' (Relph, 1986, p. 3; Norberg-Schulz, 1976). Other useful understandings here include the idea of place as being a structure of feeling or generated by 'fields of care' (Tuan, 1976), as open and relational rather than bounded (Massey, 2005), or, even more fundamentally, as that which 'is integral to the very structure and possibility of experience' and 'within and with respect to which subjectivity is itself established' (Malpas, 1999, pp. $32 \&$ 35). These more complex understandings of place can be seen to be compatible with the idea of place in CMC (see Adams, 1998). However, importantly, such understandings are rarely employed in the writing on CMC from the period under examination here (especially in the more populist and 'boosterist' literature). Some of these more complex or nuanced understandings of place and their value for understanding CMC are drawn out more fully in the later section of this paper.

\footnotetext{
${ }^{1}$ This discussion is specifically concerned with architectural and urban metaphors, while recognising that the suite of metaphors of place drawn on in the literature on CMC and 'cyberspace' forms a much broader range (see, in particular, Adams, 1997).

${ }^{2}$ For instance, The Australian Concise Oxford Dictionary offers thirteen variations, which range from broad reference to space and its occupation, to the differentiation of types or 'sub-categories' of geographical space and the occupation of these spaces (including, in order of increasing expansion: a residence or dwelling; a group of houses in a town; a town square; a village, a town, a city; an area or region) (Hughes, Michell, Ramson, 1992, p. 863).
} 
What is of particular interest at present, however, is that in both of the two earlier examples of how place circulates in virtual discourse, place is often characterised as a constraint [missing in submitted version] (Massey, 2005, p. 94). This is explicit in much of the early, boosterist literature on cyberspace (for discussion, see Graham, 1998), and particularly cyberspace architecture (see Benedikt, 1992; Novak, 1992; Spiller, 1998). It is rather more subtle in the case of the literature on metaphor use and interface design, but place is nevertheless in many cases still cast as a constraint. Here, when place-based metaphors are appealed to, it seems to be for just that reason: because they are metaphors. CMC writers and designers may have drawn on these metaphors to invoke a sense of place, but all too often 'cyberspace' and CMC was claimed to function unfettered by place as this idea is more commonly conceived and experienced. ${ }^{3}$

Suffice it to add, however, that within critical discourse on CMC and the virtual there is strong and mounting challenge to the idea that "the physical and virtual occupy opposite positions in a dichotomous relationship [where] cyberspace exists in a separate dimension from the physical and possesses radically different, almost divine characteristics' (Ward, 1998, pp. 71-72). This more qualified stance highlights that place persists in manifold ways in relation to $\mathrm{CMC}$ and the virtual, a point that shall be returned to near the end of this paper.

\footnotetext{
${ }^{3}$ This double movement is evident most clearly in the work of William J. Mitchell. The first approach described above - where spatial metaphors are evoked to create a sense of place in on-line social settings - is detailed in Mitchell's (2000) essay 'Replacing Place'. The second approach - where computer-mediated interaction is said to operate unfettered by place - is the position essentially advanced in Mitchell's earlier book, City of Bits (1995).
} 


\section{Placing the Virtual}

Yet, a key question remains unanswered: does place extend to the space within CMC and virtual community? To put this question another way, to quote John Perry Barlow (1999), 'Is there a there in cyberspace'? Can it be argued that CMC and virtual community actually contain or consist of places?

For some commentators and virtual communitarians, the answer is, 'Yes' (Mitchell, 1995; Bruckman, 1996; Grossman, 1997). Many critics are less convinced, however. For instance, the Australian theorist Emma Rooksby develops one of the more productive and carefully formulated arguments for the latter, more sceptical position. Rooksby argues against the idea that place can and does in fact exist within CMC and virtual community for the following reasons.

One of the features of virtual community is that it is formed in part by the construction of a sense of shared social presence that occurs through absence - what is otherwise known as 'telepresence' or 'virtual presence', or communication at a distance. Rooksby argues that to create 'a sense that one is in some place that does not exist doesn't conjure up in any more than an imaginary way the place one senses' (Rooksby, 2002, p. 132). In short, 'the sense in which CMC constitutes a place in which people can or feel together will be only metaphorical' (p. 126).

Thus, in answer to the question of whether place exists within $\mathrm{CMC}$, it has been suggested that it does so metaphorically, but not in any literal sense. As Rooksby puts it 'the affect of place haunts moveable and remote institutions [like CMC] rather than constituting them' (2002, p. 128, emphasis added). As Rooksby adds at a later point: 
Absence continues to hold the status of a structural constraint in CMC, just as it does in other epistolary exchanges, and in telephonic exchanges. The possibility of rapid communication among groups as well as pairs of people does not make the metaphor any more real, although it allows a social rather than personal sense of togetherness. It too has been possible for centuries, and can be explained as people's sharing an information sphere, rather than their sharing a physical place (Rooksby, 2002, p. 135, original emphasis).

The key argument of this paper, however, is that the reduction of place to metaphor does nothing to diminish the importance and centrality of place in the discourse of the virtual. Rooksby is at pains to separate appeals to metaphor from the existence of actual places. Nevertheless, this distinction belies the persistent and subtle force that is exerted by metaphor in general. Exploring this influence, especially its implications for thinking about the ongoing significance of place in relation to virtual discourse, is the issue that is taken up at length in the remaining sections of this paper.

To do this necessitates turning to Derrida's writing on metaphor and the Western metaphysical tradition. This is necessary because the argument that is being put forward is that Derrida's critique of the use of spatial (especially architectural) metaphor in the text of philosophy parallels in many respects, and holds important implications for thinking about, the use of spatial metaphor in the discourse of the virtual. In order to tease out these implications, it is first necessary to outline Derrida's arguments about metaphor and philosophy.

\section{Architectural Metaphor in the Text of Philosophy}

Architecture and architectural metaphor can be understood to be foundational to philosophy insofar as the figure of architecture serves to 'ground' philosophical 
thought. ${ }^{4}$ As one critic writes, 'Philosophers since Plato have returned over and again to architectural figures and metaphors as a way of grounding and stabilizing their otherwise unstable philosophical systems' (Karatani, 1995, p. 5; see also BrodskyLacour, 1996, 1999).

But the conventional relationship of architecture and philosophy is very much onesided. In this relationship, the architectural 'motif' is treated as an expendable metaphor that 'can and should be discarded' (Wigley, 2002, p. 16). In other words, philosophy

produces an architecture of grounded structure that it then uses for support, leaning on it, resting within it. The edifice is constructed to make theory possible, then subordinated as a metaphor to defer to some higher, nonmaterial truth (p. 16).

In order for this to work, and for philosophy to do its 'higher' work, architectural metaphor must be controlled, kept in check. And it is precisely this very neat subordination of metaphor by and in philosophy that leads Derrida to be so suspicious of spatial metaphors and the architectural metaphor in particular. This suspicion leads him to critically examine and rethink the role of metaphor in philosophy in the following ways. Through this examination, Derrida develops the following insights.

\footnotetext{
${ }^{4}$ Derrida prefers the word 'metaphysics' to 'philosophy' in this context. As one commentator explains, for Derrida " "metaphysics" does not simply equal "philosophy", if "philosophy" is understood to be simply what is taught as such institutionally' (Lucy, 1995, p. 66). Rather, 'Derrida's "metaphysics" approximates rather to something more like the space in which ideas (or concepts) are able to be taught' (p. 66). More precisely, Spivak (1997, p. xxi) writes that, 'Derrida uses the word "metaphysics" very simply as shorthand for any science of presence'. In other words, the term 'metaphysics' is used by Derrida to designate the history of a way of thinking that "requires us not to think of the "essence" of truth as a question that needs to be thought through, but rather as the fundamental ground or necessary origin of thought in general' (Lucy, 2004, p. 240). This accords in key respects with Simon Blackburn's rendering of metaphysics as that which 'tends to become concerned [...] with the presuppositions of scientific thought, or of thought in general' (1996, p. 240). However, for simplicity's sake, I will persist with using the term 'philosophy' in most instances, but it should be recognised that this usage carries the above understandings.
} 
In his critique of philosophy's use of metaphor, Derrida's approach is not to abandon the philosophical structure of the metaphysical tradition, but to locate and reveal what this structure conceals - to 'unconceal' it, if you like. This process of 'deconstructive “shaking"' (Wigley, 2002, p. 42) may well fracture the 'ground' on which philosophy is 'erected', revealing an abyss. However, Derrida's argument, and it is a crucial point, is that, even when a structure is erected on and fractured by an abyss, this does not mean the structure will collapse. Rather, as Derrida (1997, p. 163) understands it, abyss is in fact a 'structural necessity' of all structure. Philosophical structure actually depends on and is built on the very flaws it seeks to disguise; indeed, its strength is located in these structural flaws. This insight will later prove helpful for thinking about the 'place' of place in virtual discourse.

Conceiving of structural flaws as a source of strength leads Derrida to pay close attention to the place and function of spatial metaphor (and architectural metaphor in particular) in the text of philosophy. From this close reading, Derrida proposes the argument that the traditional relationship of metaphor to discourse is in fact overturned. He writes, 'metaphor is less in the philosophical text (and in the rhetorical text coordinated with it) than the philosophical text is within metaphor' (Derrida, 1982, p. 258). Or, as he puts it elsewhere, 'When the spatial model is hit upon, when it functions, critical reflection rests within it' (2001a, p. 17). Derrida's point is that philosophy and the metaphysical tradition is 'orchestrated by what it thinks it employs' (Wigley, 2002, p. 17). This provides important insight for thinking about place and the virtual.

It has been argued that Derrida resists the traditional treatment of spatial metaphor in philosophy by demonstrating how space is 'never a contingent element that can be 
simply bracketed out in favor of some higher immutable and immaterial constant'

(Wigley, 2002, p. 70). There is much more that could be said on this point,

particularly concerning the directions that Derrida develops this argument in his own writing, especially around the notion of 'spacing'. ${ }^{5}$ However, it will suffice here to state that, even as it stands, the same point holds for virtual discourse: place cannot be bracketed out in, or made marginal to, the discourse of the virtual. In the present context, then, this too offers important insight for thinking about place and the virtual.

Finally from Derrida is his overall observation - which also serves as a summary of the preceding points - that 'metaphor is never innocent' (2001a, p. 17). On the contrary, he argues, 'It orients research and fixes results' (p. 17). For the virtual, this forms a key anxiety for many theorists and critics of the virtual, and a key reason for much of the suspicion that often attends the use of spatial and 'placial' metaphor in virtual discourse. ${ }^{6}$

\section{The Haunting Affect of Place in the Discourse of the Virtual}

Drawing on these insights, I wish to make the following argument: that place is intrinsic to but largely suppressed in our understanding of CMC and the virtual, and

\footnotetext{
${ }^{5}$ While a concern for space and 'spacing' runs throughout much of Derrida's work, it is addressed most explicitly in Derrida's interview with Jean-Louis Houdebine - even though, at least on the issue of spacing, the two appear to be talking at cross-purposes to one another (see Derrida, 1981, pp. 79-83 \& 107-108 ft 42; see also Wigley, 2002, pp. 59-95 \& passim).

${ }^{6}$ As one critic observes at length:

I believe that the employment of such terms as "space" and "cyberspace" in popular and academic writings about the computer and Internet technologies makes it seem like representations are a kind of material environment. This writing repeats and even enhances design strategies that describe synchronous settings as "rooms", Internet maps that produce unnecessary and fictive geographies, and programming that makes users' progression through sites seem like bodily movement. Such visceral renderings discourage critical interventions into Internet representations because sites seem tangible. The conflation of space-producing discourses with user investment in particular sites and identities threatens to make stereotypes "real". The represented bodies of Internet settings are "fleshed out" because there seems to be an environment that can support varied bodily processes. Computer representations can also justify the perpetuation of physical but certainly not necessary or natural conditions by mirroring material circumstances (White, 2004).

Meanwhile, another critic argues that to see cyberspace in place-based terms, leads to an 'enclosing [of] cyberspace', and the imposition of 'private property conceptions upon it' (Hunter, 2003).
} 
especially in respect to how the idea of the 'virtual' has been constructed (at least in the early, boosterist literature on it).

In developing this argument, I want to suggest that the way place-based metaphors operate in the text of the virtual can be seen to parallel the way architectural metaphors are said to operate in the text of philosophy. In making this parallel, I am also suggesting that Derrida's critique of metaphor offers fresh and productive ways for thinking about place-based metaphors in the literature on information and communications technologies and the virtual, such as in the following two interconnected points.

The first point draws on the earlier idea that philosophy 'produces an architecture of grounded structure that it then uses for support' which is then 'subordinated as a metaphor [in order] to defer to some higher, nonmaterial truth' (Wigley, 2002, p. 16). Place-based metaphors operate in a somewhat similar way in virtual discourse. The idea of place serves as the paradigm of ground as support, but is then 'subordinated' as a metaphor in order to defer to some higher 'truth' or condition which maintains that cyberspace is 'ungrounded'. In other words, place is used metaphorically as a structural (or symbolic) framework for communication and then dispensed with. As Rooksby points out, 'place' is often invoked in discussions of the social life of CMC in order to legitimate it as a valid form of social interaction and 'community', after which its function is essentially fulfilled. One possible explanation for why this occurs can be found in the observation that, 'an architectural metaphor serves less to define a sense of place than to indicate a set of social functions' (Adams, 1997, p. 159). What is more, these social functions are enabled by electronic communications which, Meyrowitz claims, operate on the understanding that 'where we are physically 
no longer determines where and who we are socially' (1985, p. 115). Thus, to argue that place can not exist in CMC except as a metaphor gives support to the idea of CMC and cyberspace as 'dematerialised', 'ungrounded'. What this does, however, is veil or deny cyberspace's ongoing 'emplacement'.

Furthermore, this rather instrumental view of 'place', which claims that it can remain only a metaphor, 'is simply a reassertion of a particular and fairly narrow view of the nature of place - a reassertion that seems to ill-accord with the complex character of the concept' (Malpas, 1999, p. 38).

The second point is interconnected with and extends the first. It draws on Derrida's argument that philosophical structure actually depends on and is built on the very flaws it seeks to disguise. Wigley takes this point even further by proposing that, 'architecture, which appears to be the good tame ornament of philosophy, is actually the possibility of philosophy' (2002, p. 92). A similar logic could be applied to the role of place metaphors in virtual discourse (especially writing on $\mathrm{CMC}$ ): that is, place, which appears to be the good tame ornament of the virtual, is actually the possibility of the virtual. What I mean by this is that the way in which place is used as a metaphor in writing on $\mathrm{CMC}$ and the virtual can be read alternatively as invoking the poststructuralist argument regarding the function of a suppressed term in an apparent oppositional pairing (Derrida, 2001b).

Perhaps the best known example of this argument concerning binary pairings can be found in Derrida's (2001b) critique of the anthropologist Claude Lévi-Strauss, especially the latter's methodological approach of 'bricolage' and its associated figure of the 'bricoleur'. The bricoleur is conceived by Lévi-Strauss (1966) as an inventive anthropological investigator who assembles a meaningful cosmology from the 
random elements encountered in day-to-day life. In constructing this figure of the bricoleur, Lévi-Strauss sets it in opposition to the 'engineer', who is said to be everything the bricoleur is not: 'rational', 'civilised', uninventive, inflexible and dull. In other words, the two notions - bricoleur and engineer - are framed according to a strict binary opposition. This has been referred to as the logic of 'totalizing negation' (Lucy, 1997, p. 99), whereby 'each of these binary oppositions produces the myth of a privileged term by producing the myth of an absolutely opposing term'. It is a myth, because with each apparent 'oppositional' pairing, not only does one term permit the very possibility of the other term, but this possibility comes about because each term contains the other, contains elements of this difference. As Derrida writes of LéviStrauss's two figures:

As soon as we cease to believe in such an engineer and in a discourse which breaks with the received historical discourse, as soon as we admit that every finite discourse is bound by a certain bricolage and that the engineer and the scientist are also species of bricoleurs, then the very idea of bricolage is menaced and the difference in which it took on its meaning breaks down (Derrida, 2001b, pp. 360-361).

In other words, 'the engineer is a myth produced by the bricoleur' (2001b, p. 360). To translate this to the present context, my argument is that the historical framing of the virtual as 'unbounded' and 'dematerialised' is a myth produced by the insistence on place as only metaphorical. Moreover, these metaphorical constructions are based on quite limited underlying conceptions of place which deny the full complexity of this concept. 
The above interconnected propositions show how place cannot be bracketed out in, or made marginal to, the discourse of the virtual. Emma Rooksby claims that place as such 'does not constitute remote' institutions like virtual communities (2002, p. 128, emphasis added). Nevertheless, to conceive of place in the above ways is to acknowledge, at very least, that place exerts considerable constitutive influence on virtual discourse.

To put the matter in spectral terms, place haunts virtual discourse. Any attempt to 'exorcise' place from virtual discourse - especially by some commentators and techno-boosterists in the 1980s and 1990s - arguably only results in a temporary 'displacement' prior to its reassertion as an ongoing haunting affect of place.

Thus, the persistence of place and the way it operates as the structural figure - the 'weakness', if you like - that structures virtual discourse means that place continues to 'haunt' or shadow information and communications technologies in general.

One further, possible part explanation for the persistence of place as an idea in relation to $\mathrm{CMC}$ exchange, and especially in the interface design of virtual communities, is that it seems to connect with growing interest in and concern for issues of 'emotion' and 'other modes of feeling' in connection with place, particularly within geography (see Thien, 2005; Davidson and Milligan, 2004; Thrift, 2004; Anderson and Smith, 2001). Such concerns have long been of interest to CMC researchers. For example, many (especially early) 'talk-and-text' studies of CMC often focus on the reliance on textual cues - appropriately named 'emoticons' - by CMC users to register emotion and feeling (for discussion, see Hine, 2002). This interest in the textual expression of emotion and feeling also often dovetails with broader concerns, such as questions of (dis)embodiment (Hayles, 1996; Shields, 
1996). However, as I have been arguing throughout this paper, such communicative considerations historically took precedence over place considerations. This is why geographical interest in emotion and feeling is especially interesting in the context of the present discussion. Of particular interest is Davidson and Milligan's contention that, "the articulation of emotion is [...] spatially mediated in a manner that is not simply metaphorical' $(2004,523)$, and that 'our attempts to understand emotion or make sense of space, are, thus, somewhat circular in nature' (524). They propose that "emotions are understandable - "sensible" - only in the context of particular places. Likewise, place must be felt to make sense' (524, original emphasis). This understanding accords with Jeff Malpas's (1999, p. 36) claim that, 'it is within the structure of place that the very possibility of the social arises'; both these positions have the potential to reorient and significantly enrich existing understandings of the emotional or 'affective' dimensions of on-line social interaction.

The haunting affect of place is also significant insofar as metaphor in general is all pervasive. Malpas's earlier criticism of metaphor notwithstanding, metaphor remains important and cannot be ignored: it spatialises language, structures the way we think, and, as Derrida has argued, is part-and-parcel of the whole history of Western metaphysics (with the discourse of the virtual situated firmly within this history). As Derrida puts it elsewhere (through the use of a double negative), 'There is nothing that does not happen with metaphor and by metaphor. Any statement concerning anything that happens, metaphor included, will be produced not without metaphor' (1998, p. 103).

In light of the inescapability of metaphor in general, Derrida's work is instructive for thinking about the virtual. It offers productive ways of approaching the issue of how 
to proceed with a critique of spatial metaphor in virtual discourse. For example, in commenting on the impossibility of thinking the 'structurality of structure' from outside Western metaphysics, Derrida writes:

There is no sense in doing without the concepts of metaphysics in order to shake metaphysics. We have no language - no syntax and no lexicon - which is foreign to this history; we can pronounce not a single destructive proposition which has not already had to slip into the form, the logic, and the implicit postulations of precisely what it seeks to contest (Derrida, 2001, p. 354).

The same is true of spatial metaphor. In the present context, what is required in relation to virtual discourse is a certain ethics of reading (as Derrida might say); a commitment to close reading that is attentive to the 'spatialising' of language and discourse through metaphor.

There are valid reasons for being suspicious of spatial metaphor in respect to information and communications technologies (for discussion, see Blavin and Cohen, 2002; see also footnote six above). But it is equally important to recollect that it is only possible to critique spatial metaphor from within, by working with and against these metaphors, acknowledging their vitality (intended here in a double sense, of importance to and animation of virtual discourse) and their ongoing relevance to understanding telecommunications technologies and the techno-social. A key aspect of this process involves being 'careful about which metaphors we use to present new ideas, lest the metaphors limit our thinking and distort our perceptions' (Whittle, 1997, p. 9). As another writer puts it, 'there are always threshold points and variations that separate the metaphor from the thing itself. Sometimes the gap is so wide that the 
translation obscures more than it reveals' (Johnson, 1997, p. 107). Thus, in this context it is perhaps worth heeding Donna Haraway's advice when she argues 'for pleasure in the confusion of boundaries, and for responsibility in their construction' (Haraway, 1991, p. 150).

Finally, these ideas - about the persistence of place, its ongoing importance as a wider concept, and its inextricable context for the virtual - enable three further observations.

\section{Further Observations and Conclusions}

These observations, with which this paper concludes, reveal at least three fundamental yet problematic assumptions concerning the conception of space and place and their 'place' in the virtual. Each of these three assumptions will be sketched in brief below.

The first of them is to erroneously think of cyberspace as singular. According to Lance Strate (1999), the term cyberspace is in fact characterised by a multiplicity of meanings. This, he argues, suggests that the phenomenon of cyberspace is 'better understood as a plurality rather than a singularity', as 'the diverse experiences of space associated with computing and related technologies' (Strate, 1999, p. 383; see also Adams, 1997, 1998; Adams and Warf, 1997). Because of this proliferation in meaning and experience, what is needed, Strate proposes, is a 'more precise linguistic map', 'a survey and taxonomy of the cyberspaces' (p. 383). This he provides in the form of a tripartite taxonomy, comprising what he calls the three 'orders of cyberspace' - 'zero order', 'first order', and 'second order' - with each order encompassing several different forms. What Strate means by each of these terms is explained as follows. 
Zero order cyberspace is concerned with ontological issues and 'is devoted to the underlying questions of cyberspace's reality' (p. 386).

First order cyberspace, according to Strate, is composed of the 'basic building blocks of cyberspace': 'physical space' ['the computer itself, the structure of its chips and circuits, its architecture'], 'conceptual space' [ 'the sense of space generated within the mind as we interact with computers'], and 'perceptual space' [which mediates or interfaces between the first two: 'the impression of space that we obtain through one or a combination of our senses"] (Strate, 1999, pp. 390-396).

Second order cyberspace represents a 'synthesis' of the 'basic building blocks' which make up the first order. Also referring to this second order as 'cybermedia space', Strate suggests it is 'the sense of space generated through the user's communication with and through computers and related technologies' (p. 400).

Strate's delineation of the various forms of cyberspace highlights a number of important points that have a direct bearing on the argument of this paper.

For example, discussing cyberspace in the plural ensures a 'grounded emphasis on difference' (Strate, 1999, p. 383). Yet, what becomes apparent through this taxonomy is that, in the literature on cyberspace and place, not all forms are granted equal coverage - some are clearly favoured over others. A key example of this is the privileging of 'conceptual cyberspace' over 'physical cyberspace'. As Strate observes:

The one variety [of cyberspace] that is often overlooked is physical cyberspace, the material base of computers, monitors, disk drives, modems, wires, etc., and their users. Most discussions instead focus on conceptual 
cyberspace, the sense of space generated within the mind as we interact with computer technology (Strate, 1999, 384).

Such a partisan approach has a number of consequences. One consequence of overlooking the 'physical cyberspace' of computers and their users is a kind of 'aporia' or amnesia where it is sometimes forgotten that 'contributors to CMC discussions are spread out over a multitude of places, which they inhabit in a bodily sense' (Rooksby, 2002, 131). Thus,

To overlook this proliferation of places (and contexts) from which CMCs are sent is to risk ignoring important differences among those using $\mathrm{CMC}$, such as the different fields of action open to different persons using $\mathrm{CMC}$, or the range of shared actions possible for members of a CMC community, given their lack of propinquity (Rooksby, 2002, 131).

But perhaps the key implication of privileging 'perceptual cyberspace' over 'physical cyberspace' in the present context is that 'cyberspace is almost always seen as nonphysical space' (Strate, 1999, p. 131). For example, cyberspace has been described as a space 'parallel' to geographical space (Tække, 2002), one which invokes 'a tantalizing abstraction [...] of disembodied immersion in a "space" that has no coordinates in actual space' (Tofts and McKeich, 1998, p. 15). Importantly, however, Strate (1999, p. 389) points out that 'a physical basis for all forms of cyberspace can be established that is consistent with the physical basis of our everyday life'.

The above approach is important in that, to acknowledge the multiplicity of cyberspace and especially its material base is also to acknowledge the ongoing importance and influence of place for and in virtual discourse. 
The second assumption that needs to be attended to here concerns the all-too-frequent counterposition of space and place. This is particularly strong in virtual discourse, where the first of these two terms is often privileged over the second on the basis that space is considered 'more abstract' than place, and therefore most befitting of a realm claimed to be 'dematerialised'. According to Doreen Massey, however, this is not necessarily (or not always, and certainly not strictly) the case. 'In an age of "globalization", Massey (2002, pp. 24-25) writes, space 'is no more than the sum of all our relations and connections (friendly and antagonistic) and, like place, it too is continually being made'. Thus,

Precisely because space on this reading is a product of relations-between, relations which are necessarily embedded material practices which have to be carried out, it is always in the process of being made (Massey, 2005, p. 9).

'Not to see space in this way', she argues, "is to understand it as "abstract"' (Massey, 2002, p. 25).

This point also emphasises the social construction of place, its 'production' through individual action, social interaction, and political and economic processes (Lefebvre, 1991; Harvey, 1990). The point here is that these complexities of spatial and 'placial' production are far from adequately accounted for in the populist and boosterist accounts of cyberspace and CMC from the 1980s and 1990s. This is a problem, not least because, as Lefebvre (1991, p. 41) argues, the 'perceived-conceived-lived triad (in spatial terms: spatial practice, representations of space, representational space) loses its force if it is treated as an abstract "model"”, as it so often historically has been in the discourse of the virtual. Although, it is acknowledged that this situation has changed significantly since this period, both in subsequent critical treatments of 
cyberspace and CMC, as well as in an array of more recent research on mobile technologies and as a result of what has been termed the 'spatial turn' in media studies more generally (Falkheimer and Jansson, 2006).

The second assumption above also assumes a third: that place 'be conceptualized in a particular way: as local and bounded' (Massey, 1992, p. 15). It is on the basis of this understanding that place in virtual discourse is seen as both antithetical to teletechnologies (because place is believed to be fixed and bounded geographically) as well as undesirable (due to its historical associations with practices of domination and exclusion). Yet, as Massey (1992, p. 15) remarks, places 'do not have to be thought in that way'. For Massey (2005, p. 99), place is the 'sphere of heterogeneity, $[\ldots]$ of relations, negotiations, practices of engagement, $[\ldots]$ of coevalness, [and] of radical contemporaneity'. This is what she calls the 'event of place', which, in turn, calls for an engaged and ethically responsible 'politics of place' (2005, pp. 141-142).

To follow Massey's lead and conceive of and engage with space and place in this way is to open up a very different and potentially productive line of thought for understanding the interactions of space and place and teletechnologies (on this, see Rodgers, 2004). As Massey (2005, p. 91) puts it, 'the really serious question which is raised by $[\ldots]$ "the communications revolution" and by cyberspace, is not whether space [and place] will be annihilated but what kinds of multiplicities (patternings of uniqueness) and relations will be co-constructed with these new kinds of spatial configurations'. And, as I have argued throughout this paper, recognising the significance and accounting for the impact of metaphors of place in the discourses on these technologies and spatial configurations is equally vital. 


\section{References}

Adams, P. C. (1997), Cyberspace and virtual places, The Geographical Review, 87(2), April, pp. 155-171.

Adams, P. C. (1998), Network topologies and virtual place, Annals of the Association of American Geographers, 88(1), pp. 88-106.

Adams, P. C., and Warf, B. (1997), Introduction: Cyberspace and geographical space, The Geographical Review, 87(2), April, pp. 139-145.

Anderson, K., and Smith, S. J. (2001), Editorial: Emotional geographies, Transactions of the Institute of British Geographers, 26, pp. 7-10.

Barlow, J. P. (1999), Is there a there in cyberspace?, Utne, 15 September, available at www.utne.com/web_special/web_specials_archives/articles/611-1.html, accessed 14 January 2005.

Benedikt, M. (1992), Introduction, in: Benedikt, M. (ed.), Cyberspace: First Steps (Cambridge, Massachusetts: MIT Press), pp. 1-25.

Blackburn, S. (1996), Oxford Dictionary of Philosophy (Oxford: Oxford University Press).

Blavin, J. H., and Cohen, I. G. (2002), Gore, Gibson, and Goldsmith: The evolution of internet metaphors in law and commentary, Harvard Journal of Law \& Technology, 16(1), Fall, pp. 265-285.

Brodsky-Lacour, C. (1996), Lines of Thought: Discourse, Architectonics and the Origins of Modern Philosophy (Durham, North Carolina: Duke University Press). 
Brodsky-Lacour, C. (1999), Architecture in the discourse of modern philosophy: Descartes to Nietzsche, in: Kosta, A. and Wohlfarth, I. (eds), Nietzsche and 'An Architecture of Our Minds' (Los Angeles: The Getty Research Institute for the History of Art and the Humanities), pp. 19-34.

Bruckman, A. (1996), 'Finding one’s own space in cyberspace, Technology Review, 99(1), pp. 48-54.

Davidson, J., and Milligan, C. (2004), Editorial: Embodying emotion sensing space: Introducing emotional geographies, Social and Cultural Geography, 5(4), December, pp. 523-532.

Derrida, J. (1981), Positions, interview with Jean-Louis Houdebine and Guy Scarpetta, in: Derrida, J., Positions (trans. Alan Bass) (Chicago: The University of Chicago Press), pp. 37-96.

Derrida, J. (1982), White mythology: Metaphor in the text of philosophy, Margins of Philosophy (trans. Alan Bass) (Hemel Hempstead, Hertfordshire: Harvester Wheatsheaf), pp. 207-271.

Derrida, J. (1997), Of Grammatology (trans. Gayatri Chakravorty Spivak), corrected edition (Baltimore and London: The Johns Hopkins University Press).

Derrida, J. (1998), The retrait of metaphor (trans. F. Gasdner), in: Wolfreys, J. (ed.), The Derrida Reader: Writing Performances (Lincoln, Nebraska: University of Nebraska Press), pp. 102-129.

Derrida, J. (2001a), Force and signification, in: Derrida, J., Writing and Difference (trans. Alan Bass) (London and New York: Routledge), pp. 1-35. 
Derrida, J. (2001b), Structure, sign and play in the discourse of the human sciences, in Derrida, J., Writing and Difference (trans. Alan Bass) (London and New York: Routledge), pp. 351-370.

Falkheimer, J., and Jansson, A. (eds) (2006), Geographries of Communication: The Spatial Turn in Media Studies (Göteborg: Nordicom).

Gibson, W. (1993), Neuromancer (London: HarperCollins).

Graham, S. (1998), The end of geography or the explosion of place? Conceptualizing space, place and information technology, Progress in Human Geography, 22(2), pp. $165-185$.

Grossman, W. M. (1997), net.wars (New York: New York University Press).

Haraway, D. (1991), Simians, Cyborgs, and Women: The Reinvention of Nature (London: Free Association Books).

Harvey, D. (1990), Between space and time: Reflections on the geographical imagination, Annals of the Association of American Geographers, 80(3), pp. 418-434.

Hayles, N. K. (1996), ‘Embodied Virtuality’, in: Moser, M. A., and MacLeod, D. (eds), Immersed in Technology: Art and Virtual Environments (Cambridge, Massachusetts: MIT Press), pp. 1-28.

Hine, C. (2002), Virtual Ethnography (London: Sage).

Hughes, J. M., Michell, P. A., and Ramson, W. S. (eds) (1992), The Australian Concise Oxford Dictionary, second edition (Melbourne: Oxford University Press). 
Hunter, D. (2003), Cyberspace as place, and the tragedy of the digital anticommons, California Law Review, 91(2), March, pp. 439-519.

Johnson, S. (1997), Interface Culture: How New Technology Transforms the Way We Create and Communicate (San Francisco: HarperEdge).

Karatani, K. (1995), Architecture as Metaphor: Language, Number, Money (trans. Sabu Kohso, ed. Michael Speaks) (Cambridge, Massachusetts: MIT Press).

Knack, R. E. (2000), Hanging out: Teens search for the perfect public place, Planning, 66(8), August, pp. 4-9.

Lefebvre, H. (1991), The Production of Space (trans. Donald Nicholson-Smith), (Oxford: Blackwell).

Lévi-Strauss, C. (1966), The Savage Mind (trans. George Weidenfeld and Nicolson Ltd), (London: Weidenfeld and Nicolson).

Lucy, N. (1995), Debating Derrida (Carlton South, Victoria: Melbourne University Press).

Lucy, N. (1997), Postmodern Literary Theory: An Introduction (Oxford: Blackwell).

Lucy, N. (2004), A Derrida Dictionary (Oxford: Blackwell).

Malpas, J. (1999), Place and Experience: A Philosophical Topography (Cambridge: Cambridge University Press).

Manovich, L. (n.d.), Navigable space, available at http://www.crac.org/htmls/levspace.html, accessed 21 October 2006. 
Marshall, J. (2001), Cyber-space, or cyber-topos: The creation of online space, Social Analysis, 45(1), April, pp. 81-102.

Massey, D. (1992), A place called home?, New Formations, 17, Summer, pp. 3-15.

Massey, D. (2002), Don't let's counterpose place and space, Development, 45(1), March, pp. 24-25.

Massey, D. (2005), For Space (London: Sage).

Meyrowitz, J. (1985), No Sense of Place: The Impact of Electronic Media on Social Behavior (New York: Oxford University Press).

Mitchell, W. J. (1995), City of Bits: Space, Place, and the Infobahn (Cambridge, Massachusetts: MIT Press).

Mitchell, W. J. (2000), Replacing place, in: Lunenfeld, P. (ed.), The Digital Dialectic: New Essays on New Media (Cambridge, Massachusetts: MIT Press), pp. 112-128.

Norberg-Schulz, C. (1976), The phenomenon of place, Architectural Association Quarterly, 8(4), pp. 3-10.

Novak, M. (1992), Liquid architectures in cyberspace, in: Benedikt, M. (ed.), Cyberspace: First Steps (Cambridge, Massachusetts: MIT Press), pp. 225-254.

Rodgers, J. (2004), Doreen Massey: Space, relations, communications, Information, Communication and Society, 7(2), June (2004): 273-291.

Rooksby, E. (2002), E-mail and Ethics: Style and Ethical Relations in ComputerMediated Communication (London and New York: Routledge). 
Shields, R. (ed.) (1996), Cultures of Internet: Virtual Spaces, Real Histories, Living Bodies (London: Sage).

Spiller, N. (1998), Digital Dreams: Architecture and the New Alchemic Technologies (London: Ellipsis).

Spivak, G. C. (1997), Translator's preface, in: Derrida, J. (trans. Gayatri Chakravorty Spivak), Of Grammatology, corrected edition (Baltimore and London: The Johns Hopkins University Press), pp. ix-1xxxvii.

Strate, L. (1999), The varieties of cyberspace: Problems in definition and delimitation, Western Journal of Communication, 63(3), Summer, pp. 382-412.

Tække, J. (2002), Cyberspace as a space parallel to geographical space, in: Qvortrup, L. (ed.), Virtual Space: Spatiality in Virtual Inhabited 3D Worlds (London: Springer), pp. $25-46$.

Thien, D. (2005), After or beyond feeling? A consideration of affect and emotion in geography, Area, 37(4), December, pp. 450-456.

Thrift, N. (2004), Intensities of feeling: Towards a spatial politics of affect, Geografiska annaler, 86B(1), pp. 57-78.

Tofts, D., and McKeich, M. (1998), Memory Trade: A Prehistory of Cyberculture (North Ryde, Sydney, N.S.W.: 21C / Interface).

Tuan, Y.-F. (1976), Space and Place: The Perspective of Experience (Minneapolis: University of Minnesota Press). 
Ward, K. (1998), The emergence of the hybrid community: Re-thinking the virtual/physical dichotomy, Space and Culture, 1(4-5), pp. 71-86.

White, M. (2004), Re: first post (an internet without space), posted to air-1@aoir.org list, 3 February, accessed 6 February 2004.

Whittle, D. (1997), Cyberspace: The Human Dimension (New York: W. H. Freeman).

Wigley, M. (2002), The Architecture of Deconstruction: Derrida's Haunt (Cambridge, Massachusetts: MIT Press). 


\section{University Library}

\section{- M M I N E R VA A gateway to Melbourne's research publications}

Minerva Access is the Institutional Repository of The University of Melbourne

Author/s:

Wilken, $\mathrm{R}$

Title:

The Haunting Affect of Place in the Discourse of the Virtual

Date:

2007-03

Citation:

Wilken, R. (2007). The Haunting Affect of Place in the Discourse of the Virtual. Ethics, Place \&amp; Environment, 10 (1), pp.49-63. https://doi.org/10.1080/13668790601150545.

Publication Status:

Published

Persistent Link:

http://hdl.handle.net/11343/34637 